This item was submitted to Loughborough's Research Repository by the author.

Items in Figshare are protected by copyright, with all rights reserved, unless otherwise indicated.

\title{
Wet paint: Visual culture in a changing Britain - a round table debate
}

PLEASE CITE THE PUBLISHED VERSION

http://dx.doi.org/10.1080/14714787.2015.991620

PUBLISHER

(c) Taylor \& Francis

VERSION

AM (Accepted Manuscript)

\section{PUBLISHER STATEMENT}

This work is made available according to the conditions of the Creative Commons Attribution-NonCommercialNoDerivatives 4.0 International (CC BY-NC-ND 4.0) licence. Full details of this licence are available at: https://creativecommons.org/licenses/by-nc-nd/4.0/

\section{LICENCE}

CC BY-NC-ND 4.0

\section{REPOSITORY RECORD}

Richardson, Craig. 2019. "Wet Paint: Visual Culture in a Changing Britain - a Round Table Debate". figshare. https://hdl.handle.net/2134/23445. 


\section{'Wet Paint' - Visual Culture in a changing Britain' \\ A roundtable debate.}

Recent and future political decisions regarding the inter-regional and international partnerships which constitute Great Britain, including Scottish Independence, EVEL (English Votes for English Laws) and proposed legislation on an 'in/out' referendum on British membership of the European Union, have contributed to, and intensified, the examination of British institutions, as well as its national emblems and archetypes. In light of such dynamism we solicited contributions from representatives of the British Universities, Museum sector and Research Centres to respond to the idea of a changing Britain through the prism of British art and visual culture, using cogent examples wherever possible, and bringing to the fore their observations, understandings and positions within this rapidly developing context.

Craig Richardson

\section{Ysanne Holt}

\section{From the Borderlands}

In the round table discussion that launched the very first issue of Visual Culture in Britain in 2000, Jonathan Harris observed that accounts of the impact of globalization on academics and their disciplines necessarily called into question the formation of our sense of self, the extent to which some of us feel ourselves to be 'British', as opposed to 'English', or 'Welsh' or 'Scottish', and the historical contexts for such affiliations. The implication was that future contributors to the journal might consider their attachments, or otherwise, to these notions, and Jonathan pointed to 'Welsh European' Raymond Williams' assertion that the term 'Britishness' was a way of 'containing the protests and resentments of neglected and marginalized regions and minorities within an imposed general 'patriotism'. ${ }^{1}$

The frustrations expressed in the run up to and aftermath of the recent Scottish Independence Referendum has been a very clear indication of the consequences of such a longstanding containment. Inevitably this has been a very interesting time to be living and working in the far north of England too. Like me, Raymond Williams was a 'borderer'. He was born in Abergavenny, 'the Gateway to Wales', just six miles from the English border. My own upbringing was equally close to the English border with Scotland, and with crossborder family affiliations creating a hybrid identity there was understanding, but anxiety too, at the prospect of a Scottish 'yes' vote. The north of England, culturally, economically and politically isolated from London and the south-east was, it seemed, likely to experience yet more neglect.

Those anxieties apart however, a recent academic focus on rethinking concepts of marginal, peripheral or 'at edge' contexts such as northern borders, has underlined the extent to which these essentially dynamic and fluid spaces can serve as future models of cooperation and collaboration - positive borderlands, not sites where opposing forces with distinct interests range on either side of a territorial divide. There is indeed an over-layering cross-border legacy here, a shared emotional heritage and visual and material culture of everyday life to be observed in this particular English-Scottish location that provides an important context for thinking about place in relation to structure of feeling, and accords well with that expressed in Williams' 1960 novel, Border Country. As Jon Thompson observed, Williams' lifelong consideration was 'marginalized authors and genres, attempts to problematize the 'selective traditions' and canons that have become the recognizable borders of literary studies'. ${ }^{2}$ This specific moment in history and this particular northern border

\footnotetext{
${ }^{1}$ Harris, Jonathan, Visual Culture in Britain, Vol.1, No. 1 (2000) pp. 4-5.

2 Thompson in Dworkin, Dennis and Roman, Leslie G., Views beyond the Border Country: Raymond Williams on Cultural Politics, London: Routledge, 1993, p. 4. I set out some of these thoughts and an
} 
location provide an ideal vantage point from which to re-consider the flow of relations not just between global and national, but also regional and local traditions and identities. It's a very good position from which to review the practices, past and present, that effectively produce this borderland and to consider the potential implications (and available support) for emerging cultural forms. It is overall a perfect place to reflect anew on the distinctions outlined fourteen years ago between a journal entitled Visual Culture in Britain and notions of a British Visual Culture.

\section{David Peters Corbett}

\section{Untitled}

Nothing succeeds like success; and success is nothing if it is not sustained and consistent. In the context in which Visual Culture in Britain lives and has its being - the context of 'studies in British art and visual culture', if you like - that means it is necessarily institutional in nature. I'll try and explain what I mean. Because I'm an art historian (rather than a historian of visual culture), I'm going to concentrate on the environment that I know best.

It is perhaps easy now to forget how far British art at, say, the turn of the century was the poor relation compared to the prestige and glamour of studies in modern French art. When $V C B$ was founded in 2000 the organization of art history, the literature on modern art that then existed, the routine assumptions, and the sheer accumulated weight of attention and traditions of scrutiny, all combined to make "British art" something that still needed to be argued for as a category of study worthy of attention in its own right. It seemed important to clear some space in which this topic of study could be recognized, could receive attention which was not coloured by assumptions about value or achievement, and where a sustained communal effort of scrutiny and understanding could take place. A new journal, devoted to the field, marked an important moment in a broader process of defining British art and visual culture as a significant and vigorous area of study.

The idea of a national school is notoriously taken to carry with it ungovernable implications of mystical or transcendent qualities somehow posited as part of core identity and operating to exclude, control and discipline in socially unwholesome ways. I want to say that we need not fall into that error, and, moreover, that the advantages of proposing 'British art' as a category to be studied are substantial, if strictly pragmatic. All academic disciplines operate in a ramifying institutional context. If you are in an acceptable, and reasonably wellpopulated, academic category you are recognizable: by publishers, by departments and universities who might employ you, by the editors of journals, and by funders of all complexions. "I work in this field", you can state confidently; "this book makes a contribution in this way to this series of debates".

It is the institutional presence of 'British art' in this sense that provides its major strengths as an idea. Since 2000 there has been a very substantial growth in the number of $\mathrm{PhD}$ students at work in the field. There are concentrations of such students at - among others - the universities of York, Bristol, Warwick, and East Anglia, as well as at the Courtauld Institute, and it is noteworthy that three of the appointments to Research Fellowships in History of Art at Cambridge since 2011 have been in British art. That situation evidently contributes to the institutional strength of British art, but is also a consequence of the strength that has developed since VCB first appeared and to which it has contributed.

The need for institutional presence - which we ignore at our peril - doesn't mean that we are unable either to define the field at moments, or to adjust the category within which we make and promulgate knowledge. For some time now it's been the case that 'British art' has been responding to the interest in the global, the transatlantic, and the post-colonial in ways 
that inflect and open up the nature of the field. British art is not a fixed category, and it's as capacious as we want it to be. It certainly doesn't have to confine itself only to work that's somehow certified to be bona fide 'national' British. What's important is that we have a conceptual category in which to focus work and through which to be understood. What's not important is getting ourselves into a position where we imagine that category has any claims on the limits of our interest. We can, if we wish, simply let the phrase float, not worry too much about its incoherencies and permeable boundaries, its potential inclusions and exclusions, indeed embrace its potential for fluidity. It is a shorthand term that allows us to sustain a recognizable institutional presence, and that is too valuable an asset to be put aside. $V C B$ has been both a means of reinforcing that presence and of questioning and revising its assumptions. That can only be a good thing.

\section{Sarah V. Turner}

\section{British Art, Cultural Internationalism and the Imperial Turn}

The borders of 'British art' have been brought under scrutiny in recent months in the lead up to and period of reflection after the Scottish Independence Referendum prompting art historians to think seriously about the implications of national categorisations in relation to the organisation of art works, artists and histories of art. The project of interrogating the parameters and definitions of British art was certainly well underway way before this summer, but the debates surrounding the Referendum nevertheless forced art historians, and museum curators in particular, to think about the ramifications of such questions beyond the confines of a merely academic exercise. Examining the dynamics of cultural inter-relations within the British Isles draws attention to borders - internal ones, yes - but external ones too. Asking how art and visual culture in Britain relates to the rest of the world is an urgent project, and not just for contemporary art and practice, but also for how we conceive of the histories of British art too. Putting art and visual culture in Britain into - or back into - its international contexts opens up new routes in and out of a field that once perhaps seemed quite small and fairly closed off, even from close neighbours in the rest of Europe, never mind further afield.

One area that seems particularly alive to questioning the ways in which international cultural encounters have shaped British art and visual culture concerns what might be called, very broadly, art and empire studies. A wave of new and often methodologically provocative research is situating questions of race, representation and colonialism at the centre, rather than the margins, of British visual culture. The artistic relations between Britain and South Asia have received particularly close attention in this respect and, to my eyes, historians of eighteenth- and nineteenth-century visual culture have led an interrogation of what the colonial has to do with British art. ${ }^{3}$ Having said this, compared to the rest of the humanities, historians of British art have been relatively slow to consider the relationships between art and the British Empire, to make an “imperial turn”. In 2007, Tim Barringer, Geoff Quilley and Douglas Fordham wrote in the introduction to their edited collection Art and the British Empire (a project that stemmed from a 2001 conference on 'Art and the British Empire' held at Tate Britain in 2001 and sponsored by the Paul Mellon Centre) that their central premise was the 'the concept of empire belong at the centre, rather than in the margins, of the history

\footnotetext{
${ }^{3}$ I am thinking in particular of Natasha Eaton's work, especially her recent book Mimesis across Empires: Artworks and Networks in India, 1765-1860 (Durham: Duke University Press, 2013) and her article 'Enchanted Traps: The historiography of art and colonialism in 18th-century India', Literature Compass, 9.1 (February, 2012). Tim Barringer, Geoff Quilley and Douglas Fordham’s edited collection also opened up many important methodological questions for this field. See T. Barringer, G. Quilley and D. Fordham, (eds.), Art and the British Empire (Manchester and New York: Manchester University Press, 2007).
} 
of British art. ${ }^{44}$ In 2014 (only seven years since the publication of this statement) this might now seem like something of a given, but let's not forget the radicalism of such a call and the amount of work still to be done in responding to it. As these authors noted it was a sentiment that ran contrary to virtually the entire existing historiography of the subject.

The administrative grids of the British Empire which criss-crossed the globe undoubtedly facilitated the circulation and movement of art objects and artists, creating complex networks of artworks and human beings, opening up new channels of contact and communication that we are only beginning to reckon with.

How do we account for these rich, intertwined and multidirectional histories of British art and visual culture? How do the histories we write account for both the real and imaginative journeys that British art and artists made abroad, as well as the ways in which artists from outside of Britain responded (and are responding) to British culture? This is not simply about tracking the export of British art and the migration of British artists across the globe, but also acknowledging the 'cosmopolitics' of the journeys made by many artists from colonised countries who came to Britain to be educated in art schools or establish a career. And this is not simply about re-evaluating artists and artworks that were once neglected, but rather about putting pressure on the entire historiography of British art. The ethical edge to the 'worlding' British art makes us look outwards, but also inwards - empire, as scholars such as Catherine Hall have stressed, is not simply something 'out there' but also lived and experienced 'at home'. Asking how visual representation and imagery register the international encounters and exchanges made in the colonial spaces of Britain and the British Empire is not just a task for art historians of eighteenth-, nineteenth- and early twentiethcentury visual culture either. We also need to ask how Britain's imperial pasts shape the contemporary too.

\section{Jonathan Harris}

\section{The Global Future for British Art}

Arguably, the most important contributions within the debate on the interrelations of globalization, contemporary art and visual culture over the last fifteen years or so have matched the energy and urgency that some postmodernist writing demonstrated in the 1980s, as well as the classic 'new art history' texts of earlier decades. (Although John Barrell concluded in a recent review of the National Museum of Wales' Richard Wilson exhibition that David Solkin's 1982 Tate Gallery show and catalogue set a standard for asking such fundamental 'social art-historical' questions that Cardiff's effort in 2014 utterly failed to reach. $)^{5}$ Within all three intellectual formations, the most compelling interventions have been characterized by informed interrogation and reasoned speculative investigation. These selfconsciously 'critical practices' all prompted significant re-examination of mutuallyimplicated academic disciplinary procedures, historical and contemporary art along with an ever-widening array of visual-cultural forms. Further, the best in each have also organically entailed radical socio-political aims extending this critical-creative energy and urgency significantly beyond academe into the transforming public spheres that were simultaneously core objects of their analytic scrutiny. They've had 'impact,' then, to use a recently much abused term.

'Global,' however, can mean a bewildering variety of contested things, both literal and metaphorical. Gregor Muir's conclusion to his admittedly entertaining if inveterately annoying memoir Lucky Kunst: The Rise and Fall of Young British Art (published a year or so

\footnotetext{
${ }^{4}$ T. Barringer, G. Quilley and D. Fordham, (eds.), 'Introduction', in Art and the British Empire, p. 3.

${ }^{5}$ See the good selection of essays and bibliographic references in Filipovic, Elena; Van Hal, Marieke; Ovstebo, Solveig (eds.) The Biennial Reader, Bergen Kunsthall: Bergen, 2010. John Barrell, London Review of Books, 25 September 2014: 36-7.
} 
after the 2008 Crash) valuably indicates the extent to which this term's usage may remain finally conservative - for those, like himself, who managed to join a newly minted contemporary art establishment bolted emphatically on to London, rather than to any sense or experience of 'England' or ‘Englishness' (let alone ‘Britain' or ‘Britishness'). By 2001 Muir had got a job as a curator with Tate Modern. By then, he tells us, London, 'once a dump, had been civilized.' All those years Muir spent 'messing around in Camberwell, the Groucho Club, Cologne and New York' had finally paid off. London 'could no longer be accused of being a provincial backwater. It belonged to the future.' A literary North Of England - plus a few nooks in Urban Working Class Scotland - has a few walk-on parts in Muir's book only as the place from which some key future YBAs had to escape, while spending its then streetcred counter-cultural capital, in order to help create the London Redux over which he fawns.

Muir's account fully resumes the clichéd avant-garde narrative of old, including the touching if vacuous faith in a 'future' that YBA London's putative artistic supremacy by 2000 or so necessarily entailed. 'Global' means here - also as usual - holding up one's own in competition with, or outshining, other modern art capitals in Western Europe and New York, of course, whose decisive 'conquering' features as the mid-section of Muir's book. This storyline replays earlier well-known adventures in London's 'creative industries' conquerings of New York. The Beatles did it first - though they were only ambiguously 'from Liverpool' by 1964, given that Brian Epstein had transferred their corporate base to incipiently Swinging London the previous year. One of the earliest uses - brandings - of the term 'Young British Art' had been in Cologne, at the 1993 'UnFair', a kind of off-Broadway event to the Cologne Art Fair. This 'Junge Britische Kunst'exhibition brought together soon-to-be canonical works from the Saatchi Collection. (In an uncanny narrative-structural replication, then, the YBA were partially created through their own Germanic prefiguration, readied for an assault upon the globe as The Beatles themselves, almost thirty years earlier, had staged their crucially formative debut sessions at the Star Club in Hamburg!)

While in the PRC just as the Scottish Referendum was taking place I was interested to note that all of the Chinese I talked to, perhaps with their eyes on the 'global future' of Hong Kong and Tibet, were strongly in favour of Scotland remaining a part of the UK - or the YooKay, as Raymond Williams idiosyncratically derided what he called this 'administrative-military' referent back in the 1980s. What of the global future for 'British art'? The category remains amenable to interrogation and reasoned speculative investigation, under our global, and still globalizing, conditions. However, it is the prepositions that seem to be begging all the hard analytic (and speculative) questions. What does it mean now to be 'in' or 'from' or 'of' Britain? What is it to be or not to be British? What is it for something to be or not to be part of British Art? And these remain as much historical as contemporary questions. Watch this space.

\section{David Anderson}

\section{Culture in the Nations and Regions of the UK}

In September 2014, the political and cultural alienation felt by nearly half of the population of Scotland was so profound that they were prepared to face the economic and other risks of independence and vote yes. Many more Scottish citizens who voted no evidently shared some of this alienation. As do many communities in Wales, Northern Ireland and large parts of England.

The arts and media establishment - located predominantly in central London - plays a significant but rarely discussed role in this alienation. Neil MacGregor of the British Museum and some other English national museum directors talked of weighing in publicly on the unionist side, but were persuaded not to take such a divisive step.

Wales, like much of the rest of the United Kingdom, does not get its fair share of funding for the arts. The primary source of the inequity lies within England itself. 71\% of funding for the arts in the whole of the United Kingdom from trusts and foundations, 
corporate donors and private individuals goes to London institutions. The other $29 \%$ has to be shared between all the other nations and English regions.

Yet all this concentration of artistic funding - and therefore cultural power - is, in public policy terms, a failure. Despite investment of around $£ 1$ billion annually of public and private funds in arts and cultural institutions in just a few boroughs in central London, public participation levels in London are slightly lower than those across England as a whole.

Within England, the Arts Lottery has operated as a highly effective mechanism to take money from poorer communities and invest it in arts provision in London. Just five national performing arts organisations in London have received more ( $£ 315$ million) from the Arts Lottery since 1995 than the 33 English local authority areas with lowest participation, representing 6 million people, which between them have been awarded just £288 million over that period. Arts Lottery players of County Durham, for example, have contributed £34 million since 1995, but the area has received just $£ 12$ million.

This evidence of inequity and much more is dissected with clinical accuracy in two independent reports - Rebalancing Our Cultural Capital (2013) and The Place Report (2014). Arts Council England (ACE), after initially suggesting that the data in these reports was flawed, now publicly accepts that arts funding is unequal, but says that this is an historical problem, and the collapse of funding for the arts in the English regions is mainly the fault of another part of the regional funding ecosystem - the local authorities.

There is a challenge in all this for the BBC, our publicly-funded UK national broadcaster. As funding for the arts from diverse public sources remains concentrated in one small area of England's capital city, and (as research by the Sutton Trust has shown) those employed in senior positions in broadcasting are recruited increasingly from men and women from privileged backgrounds, and as the narrow circle of private support shrinks ever closer to central London, does the BBC achieve the impartiality in its coverage of the arts in the nations and regions that its Charter requires?

Hard evidence is difficult to find because, although the BBC and the BBC Trust between them conduct regular analyses of the proportion of news and arts content produced in the different nations of the UK, very little of this is made publicly available. An exception is the 2010 Four Nations Impartiality Review Follow-up report, conducted by Cardiff University, which shows that impartiality in the BBC's coverage of the arts in the Nations and Regions of the UK is the exception rather than the norm.

Why does the Tate's Turner Prize - widely perceived now to be tired and outdated continue to get blanket coverage on Network BBC, when the critically more highly regarded and international Artes Mundi Prize in Wales has never in 12 years had any BBC Network coverage?

Tony Hall, in a recent speech at the Pierhead Building in Cardiff, invited his audience to imagine Wales without the BBC. It is a fair challenge, but Wales - with its languages and cultural identities - existed long before the BBC. In turn, some in Wales might ask him to imagine a BBC that is not dominated by a London-centric perception of the world, and that better reflects the diversity of our nation's arts and cultures, our values and debates.

Why should we in the nations and regions accept such inequality? Why should Wales or Scotland or the north of England not commission London, rather than London (when it chooses) commission us? As Hugh McDiarmid said, "You cannot light a match on a crumbling wall." We must build a better and more solid one.

\section{Martin Myrone \\ Uses of the Past}

The spectacle of the 2012 Olympics opening ceremony was disorientating in several regards. It was striking, particularly, in its rendering of a British past which was more nuanced and accommodating than anyone had reason to expect; the ruralist first stages of the ceremony may have met expectations of bucolic nostalgia, but the events that followed 
encompassed industrialization and social change in a direct way, particularly in the muchcommented on sequence celebrating the foundation of the NHS, while also finding space to mark out a historical dimension to diversity with to the national part with a passage focussed on the Windrush. The whole was sufficiently evidently political in its content to elicit the infamous tweet from the Conservative MP Aidan Burley lamenting the ceremony's exhibition of 'leftie multi-cultural crap'. However compromised by the demands of vast spectacle intended for a global audience, and however dogged perhaps by the comfortable clichés of British eccentricity and an island (rather than more progressively Atlantic or transnational) perspective, the ceremony nonetheless suggested that a vision of the British past containing an acknowledgement of change, conflict and diversity could have currency. It intimated the possibility of a more politically mature vision of the past, with British history being reprocessed in unexpectedly artistically credible and self-conscious ways. What was most disorientating though, was that this took place in the context of a Britain which has seen the rise into power in Britain of David Cameron, Michael Gove, Boris Johnson and an ascendant UKIP and Nigel Farage. As is widely and frankly acknowledged, the political and social authority of a traditional elite, whether of the bluff patrician or urbane Etonian type, has been re-established. A form of Englishness (quite specifically) which had become merely laughable has come back into currency, and with it the prospect of a narrower, more limiting, vision of the national past.

Such may be confirmed by developments in the small, sheltered corner of the world which is the history of British art. There have been calls, from some unexpected quarters as well as more predictable ones, for a return to connoisseurship and a rejection of theory, social history, and 'politics' (a primly political gesture in itself, of course). Antiques Roadshow and Fake or Fortune are, apparently, the models for art historical practice now, with the discipline relegated to being a sort of parlour-game of attribution and identification. That the allotted masters of this game happen to be art dealers and self-funded amateurs rather than academics and professional curators is telling. Critical historians of art are being displaced by "Art Detectives".

In Cardiff, at the time of writing, an exhibition of the $18^{\text {th }}$ century landscape painter Richard Wilson (originating at the Yale Center for British Art) seems to exemplify this rejection of critical reflection; thirty years on from the landmark Wilson exhibition at the Tate Gallery (1982-3), curated by David Solkin, (also raised by Jonathan Harris) which noisily brought a 'New Art History' into the public realm, the arch conservatism of this new Wilson exhibition is marked out (as John Barrell has noted in his penetrating London Review of Books commentary) not so much by rejecting or contesting that earlier project's alignment of Wilson's art with the ideological claims of his patrons and supporters, but by simply ignoring those claims. Similarly turning away from subsequent work on the Welsh dimensions of Wilson's art and identity by Peter Lord (by no means simply complimentary to Solkin's account), the exhibition instead is skewed in its entire conception to focus on certain formal developments in Wilson's art in Italy in the 1750s, largely cutting out the narrative the paintings of English and Welsh landscapes which raise more culturally pertinent questions about property, authority and nation. This carefully edited version of Wilson pivots instead around a remarkably broad set of claims about his place in European art history, accounted for in progressivist terms as the influential anticipation of nineteenth-century "Romanticism" (hardly convincingly, as Barrell carefully observes). Elsewhere, at Tate Britain, we have seen this year the Kenneth Clark exhibition, which was so unduly respectful of its subject that I'm told by someone who went through the Courtauld in the late 1960s that it rendered its subject almost unrecognizable. The rehabilitation of the patrician connoisseur, whether via Sunday night TV or in more scholarly contexts, should set off alarm bells, and I have to wonder whether we, as the 'keepers' of a cultural heritage in museums and galleries as well as the academy, need to do more in response. 


\section{Images in 'North Britain' in 2014; A (dis)United Kingdom?}

After two plus years of at all times overt, but more often flagrant, battle of myths of belonging and symbols of identity, Scotland remains British; although it is undoubtedly, resolutely and definitively Scottish first. Scotland, as a distinct nation within a union state, has never been shy about identifying and defining itself as distinct; and social and political displays of difference have only increased dramatically in the last fifty years, as the days of Empire and WWII have waned. Yet, the fact that the UK was a union state was not, almost ruinously for that state, recognized in England, let alone the intrinsic differences inherent within Scottish identity. Even Michael Billig, while recognizing the enormous importance of everyday nationalism, failed to grasp the comprehensive difference of Scotland within the UK in his work Banal Nationalism 20 years ago. Cool Britannia may have been about to arrive in England, but it failed to resonate in Scotland, where Britishness has been on the wane.

Even while accepting itself as part of the United Kingdom; it had become rare to see a Union flag in Scotland outside of tourist sites, government offices and other, somewhat isolated, socio-political events and locales. Nor did the 2014 Independence Referendum change this state of affairs greatly. While political messages, offering a variety of images of them and us, proliferated as Referendum Day drew nearer, the core theme of belonging remained the same. The two opposing sides within Scotland, so far apart on their vision of a future Scotland, operated politically divergent messages from a complementary position of belonging; Scottishness.

The Yes campaign was perhaps able to seize the positive high ground with the nature of its message. The saltire, most often with a bordered YES emblazoned across the flag, while not an official emblem of any sort, became the eponymous symbol of pro-independence supporters and crowds. Waved from buildings and cars, the official flag of Scotland became allied to a future vision of an independent Scotland The Yes symbol itself, a blue circle with white Yes in the centre, echoed Scotland's colours, and appeared on jacket lapels, handbags, doors, lampposts and car windows at a level of visibility that far belied the final result. The day-to-day visual political battle was one sided at best.

The pro UK Better Together campaign, later re-branded as NO Thanks as it sought to capture a greater, more visible and cohesive message, did not employ the Union flag to any great extent, although it did employ the saltire in several messages, seeking to challenge ownership of the national flag by the Yes campaign. When Union flags were waved by crowds, it would be at 'stay with us' rallies in London, or politically less acceptable Orange Order marches in Edinburgh. While the symbol for NO Thanks also sought to evoke a sense of Scottishness, with a stylized, saltire suggesting slash through the $\mathrm{O}$, it failed to provide a matching resonance among the final, silent majority. The greater number of voters may have allied to the No camp, but they did not warm to its symbols. There was no pronounced expression of British identity during the campaign and where images of Britishness were employed, they were frequently tools of attack and negativity by Yes supporters.

Messages from the Yes side spoke of the negatives of Britain, presenting the image of a place 'for the rich' whereas Scotland 'was ours'; a place of 'inequality' and the 'worst child poverty', or which simply sought to link the Union flag to 'the Tories'. Additional terms substituted for Britain were Westminster, or London; places of external agents that sought to control Scotland, or at least its future. Clearly Scotland could not be of/for such things. Yet campaign leaflets, pamphlets, postcards and posters spoke of 'we' and 'our' and 'us' habitually, whether they were produced by Yes or NO Thanks, and it was clear that they meant Scotland and the people that lived there. It was always 'our' pension, or 'our' NHS, whether the wider message advocated independence or continued union. The Yes campaign included such wide groups as English Scots for Yes or Scots Asian for Yes, but they were all 'we'. In so many ways, Scotland was different and young and vibrant, with children, from babies to young adults, appearing often, as symbols of future hope in an independent Scotland, or future fears over separation.

Who were the people in Scotland in September 2014? Scottish, of course, wherever they had come from. But they were not Tories, or British, or Imperialists. We were asked not 
to decide who we were - we have always known that. The problem seemed to be deciding who was Them.

\section{Craig Richardson}

\section{A division of British Art}

For some the only question worth asking during the recent Scottish Independence Referendum was the cultural question, just as others, such as the historian Tom Devine, voiced support - 'There has been an enormous increase in a sense of Scottishness and pride in Scottish identity which has itself been sustained by an explosion in Scottish writing and creative arts since the 1980s'. While the Yes voters were intrigued by cultural potential they are more interested in new socio-economic models, edging further away from the AngloSaxon model. And a dynamic solidarity, networked and organized, managed to raise - to an exceptional level - support for self-governance that may continue within a new movement. If the movement has influence, not just in Scotland but the UK, Scotland's social institutions will be increasingly different from the rest of the UK, accelerating regional differences, which have been evident at least as far back as the 1970s. In such a future Great Britain may soon offer to its individual subjects choices regarding which taxation and representation arrangements, suit their own political preferences, effective through residential relocation and placing extraordinary stress at the borderlines. A Federation is a likely temporary outcome.

For now, though, the term Britishness increasingly means not Greatness but Englishness. This has, in part, come about through its reverse engineering; the success of regional devolution but also in how Westminster has recently unpicked Universalism. But the cultural question remains a fruitful one to work within. And Englishness as a contemporary cultural quality is less fraughtly contested. Positive cultural aspects such as have accompanied other nationwide changes include newly found regional identities celebrated by immigrant communities (the ease with which second, third and fourth generation Indian subcontinentals resident in Scotland referred to themselves as proudly, or at least decidedly, Scottish during the Scottish Independence Referendum was very interesting). And distinctive Scottish and English self-identification is manifestly celebrated in emigrant communities elsewhere. A number of my colleagues at The University of Northumbria are exploring the vitality of Englishness abroad; recognizing the English as a distinct ethnic group, similar to the Irish, Scots and Germans, and noting for instance that the marking of St George's Day is on the rise in the US. But even during wartime Orwell wrote that 'In England the 'Rule Britannia' stuff, is done by small minorities' and overt patriotic displays are normally cringemaking. And so, as was found in the result of the Scottish Referendum, national affiliation, arguably founded upon meaningful values, images and beliefs, is often a private matter. However since 2012 there have been numerous opportunities to gauge public feeling about these matters through their visual manifestation, Jubilee, Olympics, and Referendum.

In thinking about where England goes next, culturally speaking, Scotland is not necessarily the benchmark here (and much needed postcolonial research is still in its early days) but it is increasingly distinctive. England increasingly needs its distinction from Britain / Union in order to captivate and to enable progressive ideas of allegiance to be formed by convincing contributions from a variety of sources; towards a reformed English cultural identity.

How this will effect British art institutions is going to throw up all kinds of problems. 'British Art' may well become an historic denotation. As a modern-day theory it warns 'keep off' (however like another warning - 'Wet Paint' - encounters with it yearn to be tested). The idea of Britain and how it might be utilized in visual art to corral too many disparate interests, the near impossibility of its presentation as a spectrum of alliance within an assumption of complicity (with Britishness), is almost untenable in the context of developing regional political devolution. Anyhow, in the field of contemporary British culture there is often a dominant regional inflection. This was evident in how English Magic, Jeremy Deller's 2013 
Venice Biennale British Pavilion approached English creative icons (William Morris, David Bowie) and customs (a nice cup of tea, irony) as an array of documents, experiences and artifacts; to show how the English cultural archive can be contextualized in relation to political discourses and contribute to an explicit English Art, and chimes with Martin Myrone's description of sections of Danny Boyle's 2012 Olympics ceremony as national facets "reprocessed in unexpectedly artistically credible and self-conscious ways". Another exemplar, Mark Wallinger’s poignant State Britain (2007), centred on the unrepresented persona of Brian Haws' during his 10-year protest and peace campaign between 2001-11 in Parliament Square, London. Haws' condemnatory banners and retching-horrific imagery of the injured and dead of Britain's war in Iraq and Helmand were impeccably re-rendered. In Deller's England a land of living rituals is found amidst the remnants of lost kingdoms. A chippy solidarity is found in Wallinger's critical work, England's loner critics repeatedly point to the need for veracity in law, just as England keeps bending the rules and flirting with danger, in sport, finance or governance. 'English Art' may remain highly contestable, but artists can work within such regional historical inflections and their contradictory contemporary manifestations.

\section{Dana Arnold}

\section{Bric-a-Brac and Britishness: Trafalgar Square}

In March 2015 an equestrian statue will stand on the fourth plinth in Trafalgar Square. In a witty yet provocative gesture Hans Haacke's Gift Horse mirrors and inverts Sir Francis Chantrey's traditional sculptural portrait of George IV on horseback that has stood on plinth in the north-east corner of the square since the mid-nineteenth century. Together these atemporal pendant pieces make me think again about the relationship between London and Britishness

Trafalgar Square is indexical of the history of England, Britain, and the Empire, as well as London itself. Originally part of the area known as Charing Cross, named after one of the thirteenth-century Eleanor Crosses, the site bordered the entrance to the Palace of Whitehall the residence of the English monarchy from 1530 until it was destroyed by fire in 1698. The space was both the starting point for processions leading the condemned to be hung at Tyburn and the locus of political protest. Happily, only one of these functions endures to the present day. The site offers an archaeology of more recent socio-political events that has been ably explored by Rodney Mace. ${ }^{6}$ These range from the Social Democratic Foundation protest on $13^{\text {th }}$ November 1887, known as Bloody Sunday, to more recent occupations of the square for extended periods of time by those protesting against climate change, global terrorism and budget cuts. Trafalgar Square presents, then, diverse social and spatial practices across a broad sweep of time that underscore the fluidity of the concept of Britishness.

The equestrian connection remains strong throughout the history of Trafalgar Square as evident in the King's Mews that had origins dating back as far as 1273, but was demolished in the 1830s to make way for the National Gallery. With the threat of civil unrest and Napoleon's military ambitions in mind, the new Gallery was designed to afford access to the Barracks (only demolished in 1907) at its rear. Indeed, Nelson's Column, which might well have acted as a deterrent to any Frenchman contemplating invasion, was begun in 1839 the result of a hurried competition to provide a national monument that was as economical as it was tardy. Today the space is overrun with tourists gazing through the camera lens at the architectural bric-a-brac that somehow manages to connote Britishness in the face of homogenized global identities.

My interest lies in the nineteenth century bric-a-brac as it tells a story of nation building through an architectural aesthetic. George IV wanted splendour and John Nash provided it with a vision for London that was intended to transform London into the first city

\footnotetext{
${ }^{6}$ Mace, Rodney, Trafalgar Square: Emblem of Empire, $2^{\text {nd }}$ new edition, London, 2005.
} 
of Empire. Trafalgar Square, as it was known from 1830, became one of the focal points in the new urban topography of the newly fashionable West End and was intended to be a public open space devoted to art and culture. The design aimed to reflect the glory of ancient Greece and Rome and eclipse the Paris of Napoleon. Nash's rapid fall from grace on the death of his patron and the almost simultaneous imposition by the Duke of Wellington's, who was then prime minister, of a moratorium on spending on all public works in London may well have put an end to this vision.

But there were remnants of the grand scheme known as the Metropolitan Improvements and they were too expensive to waste. For us, they provide a memory trace of this vision of Britishness that was never to be. Moreover, this economic pragmatism in the formation of the spaces of Trafalgar Square provides a spectacle akin to aesthetic musical chairs. For instance, William Wilkins was obliged to re-use the portico and columns from the recently demolished Carlton House Palace on the façade of his National Gallery, which diminished the scale and effect of this major public building. And if we return to the equestrian statue of George IV we find further evidence of artistic recycling. It arrived on the plinth after the erection of Nelson's column and as such an admiral overshadows a monarch. The equestrian statue was intended to sit atop the Marble Arch, which was initially situated in front of Buckingham Palace before it was moved in 1852 to the western end of Oxford Street - not far from site of the now defunct Tyburn. Did the bronze effigy of George IV follow in reverse the path across the West End of London of those who had been condemned?

The recent use of the fourth plinth as a transient monument is not, then, out of kilter with the rest of the Trafalgar Square. Haacke's skeletal bronze horse makes clear historical reference to the space not least to an equestrian statue of William IV that had been planned but not realized for the fourth plinth in the 1840s. Haacke states that Gift Horse also pays tribute two Britons: the artist George Stubbs and more obliquely to Adam Smith whose Wealth of Nations (1766) explores the meaning of 'looking a gift horse in the mouth'. Perhaps more importantly, the work refers to the new visual identity of London through the electronic ribbon, which displays the tickertape of the London Stock Exchange, that is tied to the horse's front leg. Now, as a hub of global capitalism London's architectural aesthetic hinges more on the towers, rather than columns, produced by star architects in the one time unfashionable east of the city. How far this projects a British identity, or indeed an English one, is open to question, and there is certainly no room for bric-a-brac. 
Contributor's emails:

Dr Murray Stewart Leith (Murray.Leith@uws.ac.uk, University of the West of Scotland) Prof David Peters Corbett (d.peterscorbett@uea.ac.uk, University of East Anglia)

Prof Jonathan Harris (J.Harris@soton.ac.uk, Winchester Centre for Global Futures in Art Design \& Media, University of Southampton)

Dr Martin Myrone (Martin.Myrone@tate.org.uk, Tate Britain)

Prof Ysanne Holt (Ysanne.holt@northumbria.ac.uk, Northumbria University)

David Anderson, (David.Anderson@museumwales.ac.uk, Director General, National Museum of Wales)

Prof Craig Richardson (craig.richardson@northumbria.ac.uk, Northumbria University) Prof Dana Arnold (D.Arnold@mdx.ac.uk, Middlesex University)

Dr Sarah Turner (svturner@paul-mellon-centre.ac.uk, Paul Mellon Centre for Studies in British Art) 